International Journal of Canadian Studies

Revue internationale d'études canadiennes

\title{
The Government of Canada's Search for Environmental Legitimacy: 1971-2008
}

\section{Douglas Macdonald}

Numéro 39-40, 2009

Culture - Natures in Canada

Culture - natures au Canada

URI : https://id.erudit.org/iderudit/040829ar

DOI : https://doi.org/10.7202/040829ar

Aller au sommaire du numéro

\section{Éditeur(s)}

Conseil international d'études canadiennes

\section{ISSN}

1180-3991 (imprimé)

1923-5291 (numérique)

Découvrir la revue

\section{Citer cet article}

Macdonald, D. (2009). The Government of Canada's Search for Environmental Legitimacy: 1971-2008. International Journal of Canadian Studies / Revue internationale d'études canadiennes, (39-40), 191-210.

https://doi.org/10.7202/040829ar

\section{Résumé de l'article}

Bien que le terme « écoblanchiment » soit désormaisentré dans la langue, il y a peu d'analyses savantes sur la légitimitéenvironnementale comme un facteur dans des politiques sur l'environnement. Leprésent article examine les prétentions à la légitimité environnementale que legouvernement du Canada a fait valoir dans le cadre de sept initiatives politiques etdont les plus communes sont les suivantes : 1 ) les mesures prises sont plusefficaces que celles des gouvernements précédents; 2) le Canada en fait plus qued'autres pays; 3) la politique aidera l'économie ainsi quel'environnement (développement durable); et 4) le processus politiquetransparent est légitime en soi. L'exagération et la minimisation des mesuresconnexes par les provinces constituent d'autres thèmes communs. 


\title{
Douglas Macdonald
}

\section{The Government of Canada's Search for Environmental Legitimacy: 1971 - 2008}

\begin{abstract}
Although the term "greenwash" has now entered the language, there has been little academic analysis of environmental legitimacy as a factor in environmental politics. This article examines claims to environmental legitimacy made by the Government of Canada with respect to seven policy initiatives. The most common claims have been: (1) action exceeds that of previous governments; (2) Canada is doing more than other countries; (3) the policy will aid economy as well as environment (sustainable development); and, (4) the transparent policy process is itself legitimate. Exaggeration and downplaying related action by the provinces are other common themes.
\end{abstract}

\section{Résumé}

Bien que le terme «écoblanchiment » soit désormais entré dans la langue, ily a peu d'analyses savantes sur la légitimité environnementale comme un facteur dans des politiques sur l'environnement. Le présent article examine les prétentions à la légitimité environnementale que le gouvernement du Canada a fait valoir dans le cadre de sept initiatives politiques et dont les plus communes sont les suivantes : 1) les mesures prises sont plus efficaces que celles des gouvernements précédents; 2) le Canada en fait plus que d'autres pays; 3) la politique aidera l'économie ainsi que l'environnement (développement durable); et 4) le processus politique transparent est légitime en soi. L'exagération et la minimisation des mesures connexes par les provinces constituent d'autres thèmes communs.

Environmental policies implemented by Canadian federal and provincial governments since the early 1970 s have been only partially successful. The most notable success has been a reduction in the harm caused by the discharge of industrial pollution. Acid rain caused by sulphur dioxide emissions from electrical utilities and smelters, for instance, has been significantly reduced (Environment Canada, 2003 14). More complex problems, however, have not been resolved. The total quantity of solid waste generated each year continues to increase, even though the portion of that total diverted to recycling has grown (64). Motor vehicles emit less pollution per kilometre driven, but because there are more of them, urban smog remains a problem (38). Despite policy efforts dating back to 1992, total greenhouse gas emissions continue to increase annually (21).

The failure of government policies addressing these and other environmental problems can be attributed to a number of factors, including 
the political power of the regulated industries, chronic underfunding of environment departments and, the subject addressed in this issue of the Journal, Canadian societal attitudes, such as the dominant paradigm of consumption and economic growth, which influence environmental politics. The subject of this article is one aspect of those attitudes - the perceived legitimacy of actions taken by the Government of Canada to address such problems. This is important because to the extent that these actions are seen by the Canadian public as legitimate, there is less pressure to put in place more effective policies. Canada's federal government (like other governments and business corporations) devotes considerable efforts to convincing the public that they are taking effective action to protect the environment. Environmentalists refer to this as "greenwashing" (Greenpeace). For purposes of academic inquiry, the expression used here is "search for environmental legitimacy."

I define "environmental legitimacy" as the belief in the eyes of the Canadian public that the values and actions of a particular actor, such as a government, business corporation, or individual citizen, are proper and sufficient to guard against undue environmental harm. The notion will be discussed more fully below. As noted, this article examines one case of the search for environmental legitimacy-the image of its environmental policies presented to the public by the Government of Canada, and more particularly by the relevant administrative department, Environment Canada, since its creation in 1971. The research question is: How have the Government of Canada and Environment Canada worked to project to the Canadian public an image of environmental legitimacy? The federal government was selected for this case study (again, discussed more fully below) because it is less able than its provincial counterparts to achieve environmental legitimacy through policy action alone and must, therefore, rely more upon its ability to manipulate the image of its policy actions in the minds of Canadians.

The article seeks to achieve two objectives: The first is to offer a full and precise definition of environmental legitimacy and to make the argument that the concept, thus defined, is an important aspect of Canadian environmental politics which deserves more research attention than it has received to date. The second is to attempt to make an initial contribution to that needed research, by analyzing the claims which one government actor has believed will best allow it to obtain its goal of perceived environmental legitimacy.

\section{Environmental Legitimacy}

The purpose of this section is to expand upon the brief definition of environmental legitimacy set out above by discussing it as a subset of the larger subjects of "legitimacy" and "political legitimacy." The way in 
which social scientists conceptualize legitimacy can be seen in the two following definitions.

1. "The "rightfulness" of a social or political order, its claim to support, as opposed to mere acquiescence, on the part of those subject to it ... [In] twentieth-century social thought ... a regime is "legitimate" if it is believed to be legitimate by the population concerned" (Outhwaite 328; emphasis in original).

2. "Legitimacy is a generalized perception or assumption that the actions of an entity are desirable, proper or appropriate within some socially constructed system of norms, values, beliefs and definitions" (Suchman 3).

Thus legitimacy is defined as an idea (belief, perception, assumption) in the mind of the person judging the legitimacy of a given entity. As can be. seen from the second definition, there is in fact not just one idea in that mind, but two. The first is the perception of the entity whose legitimacy is being judged (and of its actions), while the second is the perception of the standard (system of norms) used for that judging. This conceptualization of legitimacy as two ideas (the entity and the evaluative standard) in the mind of the legitimacy judge is central to the assumption upon which this analysis is based respecting the ways in which an entity, whether it be an organization, a social movement or an individual, can work to obtain or restore legitimacy in the eyes of a given audience. Based on Suchman, I assume that an entity can achieve legitimacy in three ways: (1) by changing its behaviour to better fit the standard by which its legitimacy is being judged by a given audience; (2) by changing the image it presents of that behaviour to better fit those standards; and, (3) by convincing the audience it should accept a change in the standards themselves, again so that there is a better fit between the behaviour and the standard. The focus of the case study which follows is on the second means, although the other two are also relevant to this inquiry.

As defined here, "political legitimacy" simply applies the same definition to state and non-state actors (governments, political parties, lobbying interests) engaged in the political process. In the case of state actors, social scientists agree on a central point-that legitimacy is distinguished from coercion. Barker gives this definition: "[political] legitimacy is precisely the belief in the rightfulness of a state, in its authority to issue commands, so that those commands are obeyed not simply out of fear or self-interest, but because subjects believe that they ought to obey" (11). Thus the action of obeying does not confer political legitimacy, unless it is motivated by more than self-interest in the face of coercive physical power. Such coercive power, in which the subordinate threatened with death complies out of self-interest, helps to explain obedience, but does not fully define legitimacy. That definition includes the notion of "rightfulness"- the belief that one should obey, even in the absence of 
coercion. And this, of course, is why legitimacy is so directly tied to power. Physical force is one source of power and one means of exercising it. There is consensus amongst students of political power, however, ranging from Machiavelli to Gramsci, that a far more effective source is the willing consent of the governed, flowing from their perception that the power to which they are subjected is justified and morally acceptable, since those exercising it have a legitimate right to rule (Connolly; Franck; Beetham). Perceived legitimacy is so important in politics because it is an essential source of political power.

More or less by definition, all political actors, state and non-state alike, seek political power. It seems reasonable to assume, then, that all seek legitimacy in the eyes of relevant audiences because it is a source of political power and that this is equally true of actors in the arena of environmental politics.

The aspect of political legitimacy relevant to this case study is less the legitimacy of the state as a whole and more the perceived legitimacy of policies adopted by a given government. Skogstad, citing Scharpf with reference to "input" and "output" legitimacy, argues that both the process for policy development as well as the policy itself are evaluated by citizens or others determining legitimacy.

Why do we obey the rules and decisions to which those in authority collectively bind us? The answer is clear. We obey, first, because we believe that those who make legally enforceable decisions have a right to do so; and second, because we believe the decisions themselves - the public policies - are socially desirable. (955)

In the case study analysis below, I examine the ways in which the federal government has claimed that its policy process is legitimate (by pointing to such things as public consultation during policy development) as well as the legitimacy claims made for the policies themselves.

Above, I offered this definition of environmental legitimacy, with respect to a particular judge: "the belief in the eyes of the Canadian public that the values and actions of a particular actor, such as a government, business corporation, or individual citizen, are proper and sufficient to guard against undue environmental harm." To further develop that, based on the discussion above, we can use a current definition of "greenwashing."

Greenwashing is the unjustified appropriation of environmental virtue by a company, an industry, a government, a politician or even a non-governmental organization to create a pro-environmental image, sell a product or a policy, or to try and rehabilitate their standing with the public and decision-makers after being embroiled in controversy. (Source Watch Encyclopaedia) 
This definition sets out the possible entities being judged, their strategy for obtaining environmental legitimacy (appropriation, which refers to projecting an image, the second of the three means set out above) and two possible audiences doing the judging. What neither it nor my definition do is to explicitly present the standard being used by the relevant judging audience. Can we more precisely define "undue environmental harm" or "environmental virtue?" What follows are some preliminary suggestions.

What we are attempting to do is to define Suchman's "socially constructed system of norms, values, beliefs and definitions" with respect to environment, in Canada and other industrialized nations today. Space precludes anything like a full discussion, but two points can be made. First, the system of environmental norms is continually changing. It did not exist a hundred years ago (Dryzek) and ten years ago it did not include concerns over bottled water and plastic shopping bags. Why does it change? The major impetus, throughout the twentieth century history of environmental concern has always been science, with the necessary addition of the social movement of environmentalism to broadcast and inject into the public debate claims made by science. Science, however, has never been the only driver. From the origins of the animal rights movement in the early nineteenth century, to more recent concerns over "land health" and "bioequity," values associated with justice and equity have always been present (Nash; Shabecoff). Second, while continually adapting in response to changes in science and values, at any given time there is never just one set of environmental norms. Instead, there is a spectrum of positions ranging from light (mainstream) to deep green (radical). This is because the environmental movement itself is divided and because other actors, in particular business, are now also engaged in the struggle to define environmental legitimacy. Social construction of environmental norms is a process of continual contestation.

By far the most significant event in this evolving process has been the consensus which has emerged around the ambiguous concept of sustainable development. The modern environmental movement of the 1960s and 1970s sought to advance two norms, both offering radical challenges to current values: limits to growth and bioequity (Carter). By the 1980 s, however, that radicalism was in retreat.

In the early 1980s the environmental movement found new incentives, and changed its political strategies and organizational structure. The environmentalists of the 1980s were less radical, more practical, and were much more policy-oriented. The movement's emphases were no longer on alternatives for society, it started to focus on presenting practical alternatives within society instead. (Hajer 93)

The most visible expression of this change was the acceptance by mainstream environmentalism of the set of norms represented by the 
concept of sustainable development, which contained neither a prescription for limits to economic development nor a fundamental concern for the well-being of other species. Unable to gain legitimacy and associated political power as long as it maintained its original, radical norms, the majority environmental movement consented to the view that environmental protection and economic growth were not mutually exclusive goals.

At the same time, business was making its own compromises. In the nineteenth century, Rockefeller and other barons of business saw themselves as functioning in an amoral market, obeying the law but otherwise untouched by social norms. That had changed by the 1920 s, at which point big business, driven by a search for legitimacy, had agreed that it bore social responsibilities, most notably to its employees, customers and neighbours (Mitchell, 1989; 1997). During the counter-culture era of the 1960 s, business lost legitimacy on a number of fronts, including the new one of the environment. Since then, it has worked to gain environmental legitimacy, using all three strategies: improving its environmental management; engaging in advertising and public relations efforts to project a positive image of that behaviour change (Howlett and Raglon); and working to change the norms by which it was being judged, particularly by embracing the new norm of sustainable development (Macdonald, 2007). Both environmentalists and business have sought environmental legitimacy and have worked to obtain it through compromise, in the process establishing sustainable development as the central norm of environmental legitimacy (Hajer; Lafferty). As we shall see, the Government of Canada has also contributed to that process as part of its search for environmental legitimacy.

\section{Environmental Legitimacy Claims}

Since its creation, Environment Canada has faced a basic problem concerning its environmental legitimacy. This is due to the fact that governmental power to protect the environment is largely held by others, meaning that it is less able to obtain environmental legitimacy through its actions and must rely more upon its portrayal of those actions to the Canadian public. In the first sentence of their study of the department, Doern and Conway describe the problem this way: "The Department of the Environment (DOE) is the focal point for the analysis in this book, but the department has not been, as we will see, the centre of political power on environmental matters" (16). The power of the department to take policy action has always been limited by two factors: (1) its weak position within the Government of Canada; and (2) the fact that it has been almost exclusively the provinces, rather than the federal government, who have regulated pollution using the coercive, effective instrument of law. 
The first problem stems from the fact that, because environment is a "horizontal issue" touching upon almost all aspects of the Canadian economy and society, the actions of many other federal government departments, in fields such as resources, industry, health and agriculture, are as necessary and relevant as its own (Macdonald, 1991; Winfield). The department has never been given any real powers to co-ordinate the environmental activities of other federal departments or agencies (Doern and Conway; Doern). During the Chrétien era, responsibility for the most salient issue, climate change, was divided between Environment Canada and Natural Resources Canada, with the latter only established as lead department under the Martin government (Macdonald, Bjorn and VanNijnatten). Since its creation, this internal weakness has been compounded by the fact that, with a few exceptions (Charles Caccia in the Trudeau government of the early 1980 s, Lucien Bouchard, briefly after the 1988 re-election of the Mulroney government, David Anderson in the Chrétien government from 1999 to 2003, John Baird and Jim Prentice in the Harper government), Environment Canada has almost always been a relatively small department, headed by ministers who were newly elected MPs, with no particular interest or expertise in the area of the environment, and who often were shuffled out of the post after only a few months in the job (Doern and Conway).

Secondly, due in part to constitutional jurisdiction and in part to the evolution of federal-provincial co-ordination in the field, the process of environmental regulation through setting and enforcing standards, is done almost completely by provincial environment departments, using provincial law (Cotton and McKinnon). Environment Canada has rarely used federal law to directly regulate polluting firms.

In the 1970s, Environment Canada used its powers under the newly enacted federal environmental legislation to directly regulate pollution emissions of a limited number of private sector firms, most notably in the pulp and paper sector. As the provinces began to establish their own regulatory systems, and to object to what they saw as federal intrusion, this direct regulatory role was reduced. In the late 1980 s, responding to the renewed salience of environment as a political and electoral issue, the Mulroney administration, having successfully co-ordinated the 1985 national acid rain program, began to seek the electoral benefits associated with a stronger policy role (Harrison). The Mulroney government enacted the Canadian Environmental Protection Act (CEPA) in 1988, but since then it has been used primarily to regulate toxic substances as products sold on the market, rather than pollution emissions. The 1990 Green Plan, however, in part due to objections by the provinces, contained no regulatory provisions and during the 1990 s the Chrétien government moved to harmonize policy with the provinces, recognizing their primary regulatory role (Winfield and Macdonald). The one exception in the history of leaving 
emissions regulation to the provinces has been climate change policy. Since 2002, when Canada ratified the Kyoto Protocol, the federal government has been developing plans to itself directly regulate greenhouse gas emissions; regulations under CEPA were slated to take effect in 2010, but have been delayed in order to harmonize with pending US regulation (Galloway). At the time of ratification, no provincial regulations were in place. These three times that the federal government moved to more actively implement environmental policy, in the early 1970 s, late 1980 s and 2007 , were attempts to gain environmental legitimacy, and associated electoral advantage, by the first means discussed above, behaviour change. They were half-hearted, though, and never replaced primary reliance upon the second method, image projection.

Given these two constraints, the focus of the present case study is the way in which Environment Canada, and through it the Government of Canada, have sought to compensate, by means of image projection, for a lack of action to achieve environmental legitimacy in the eyes of the Canadian public. Examination is made of the image of its actions projected by the department, first in general terms in 1974, and then with respect to seven major policy initiatives: (1) the 1985 acid rain program; (2) the enactment of CEPA in 1988; (3) the 1990 Green Plan; (4) the Canadian Environmental Assessment Act (CEAA) of 1992; (5) the participation in the international Rio conference of 1992 which resulted in the Framework Convention on Climate Change and the Convention on Biological Diversity; (6) the climate change policy adopted by the Chrétien government in 2002 , the first time the federal government acted independently of the provinces on the issue; and (7) the 2007 Harper government climate change program, also unilateral, but this time more clearly forced upon a reluctant government by public opinion (Macdonald, 2008). Although far from being a complete survey of Environment Canada policies, these seven policy initiatives do provide a useful sample which includes both instances when federal regulation was either absent or less important for the program in question than provincial regulation (the Green Plan and acid rain) and, at the other end of the spectrum, instances when the program in question was anchored to direct federal regulation (CEPA, CEAA, the 2002 and 2007 federal climate change programs). The one example of action on the international stage (Rio) gives a snapshot of an area in which the federal government is less constrained by the provinces.

Actions taken by the department with respect to each of these initiatives are briefly described, followed by a description and discussion of the way in which Environment Canada or the Government of Canada presented those actions to the Canadian public. Data respecting those claims to environmental legitimacy is taken from twelve documents. The 1974 document is a government report, while all the others are speeches or statements by the environment minister or prime minister of the day, or news releases. 
Again, with the exception of the 1974 document, all are short documents, on average two to five pages, making identification of the major claims made in each a relatively straight-forward task. The "claim" is defined here as words used to describe: (1) the government itself (for instance, concerned about the environment); (2) the policy process (for instance, transparent, consultative); and (3) the policy itself (for instance, more significant than anything done by previous governments. Unlike technical documents, these speeches and news releases are intended solely to give the public a positive view of their government and so are a useful source of data respecting environmental legitimacy claims.

Three years after it came into being, Environment Canada published a short document titled Environment Canada: Its role, goals and organization. It is a sober, straightforward document which appears to provide a factual picture, without embellishment or exaggeration. The departmental mandate is presented as follows: "The Department of the Environment, also known as Environment Canada, has as its primary duty the protection of Canada's air, water and land resources" (Environment Canada, 1974 2). The limited regulatory capacity of the department is readily admitted: "Regulation and use [of resources] are largely under provincial jurisdiction"(4). The document claims that a "useful division of labour" between the two levels of government has been established and goes on to present one of the dominant, recurring themes in the documents examined: co-operation. "It is clear that environmental matters do not fall under separate federal and provincial headings. Co-operation is the key word in concept, planning and execution. This parallels the reality that the human environment is one and indivisible" (4).

Given this limited role, what claim does the document make for the legitimacy of the department's role? The answer is another recurring theme: leadership. "Although Environment Canada cannot accomplish on its own the renewable resource and environmental tasks for these important national undertakings, it can provide leadership" (6). More specifically, with respect to regulation and enforcement of environmental laws (defined above as the use of an effective, coercive policy instrument), the document states that while the provinces are expected to take the lead, the federal government will act if necessary, "'[b]ut the federal government must act directly, where it has jurisdiction, if the provinces are unable or fail to provide adequate protection. With cooperation and experience, direct federal action will be the exception" (6).

\section{The 1985 Acid Rain Program}

By the late 1970 s, acid rain, consisting of sulphur dioxide emitted by coal-burning smelters and utilities in both Canada and the US and nitrogen oxides in motor vehicle exhaust, was becoming the department's dominant concern. Between then and the conclusion of the 1991 Canada-US Air 
Quality Agreement, the federal government played a two-level game: trying to convince both the Americans and the seven most eastern Canadian provinces to put in place more effective policy. Although Environment Canada threatened to directly regulate emissions as part of its negotiations with the Ontario Ministry of Environment, at the end of the day, the 1985 federal-provincial program relied upon the provinces for that task. The federal government was charged with developing new standards for motor vehicle emissions and providing funding to assist with smelter modernization and emission reduction. The heart of the program, however, was action by the provinces, using the instrument of law, coupled in Ontario's case with an active enforcement program (Macdonald, 1997).

In two documents describing that program, a news release and a speech by the minister, the modesty and unadorned prose of the 1974 document is replaced by triumphalism. The "truly ambitious national acid rain program" is the "largest and most essential environmental program that Canada has everwitnessed"(Environment Canada, 1985). It means Canada is playing a "leadership role in the international community." The program shows how the newly elected Mulroney government has "demonstrated its concern for environmental protection in Canada." The minister's speech goes even further than the news release. Another recurring theme, the claim that the Canadian federal government is doing more than governments of other countries, appears: "[the program] will have the effect of placing Canada in the lead among the countries engaged in eliminating this problem. ... Our new motor emission standards are as tough as any other national standard and tougher than most" (Blais-Grenier). The phrase "as tough as" was necessary because the standards were simply based on US federal standards. We not only have the usual claim of cooperation, but now "an unparalleled example of cooperation" (Blais-Grenier). The superlatives continue: "The scientific investigation and monitoring program is the most comprehensive long-term effort by Canada in the environmental field. ... In short, it is the most ambitious environmental protection program even [sic] put foreward [sic] and one that is not equaled anywhere."

These two 1985 acid rain documents, in summary, provided four claims to environmental legitimacy: (1) the federal government was concerned about the issue of environmental protection and giving it priority; (2) the program was a major step forward, showing that this government was doing more than its predecessors; (3) the federal government was playing a leadership role; and (4) Canadian action compared favourably with that of other countries. In addition, although the provincial role was acknowledged, it was certainly not highlighted. The news release referred to "emission reductions to be achieved under provincial legislation" but only after describing the program's "tough new [federal] motor vehicle emission standards" (Environment Canada, March 6, 1985). 


\section{The 1988 Canadian Environmental Protection Act (CEPA)}

The 1988 CEPA consolidated a number of existing federal laws, but did not significantly expand the federal government's legislative scope. CEPA did, however, increase the upper limit on fines under federal environmental law, something which was proudly pointed to by the minister of the day. In his speech introducing the new CEPA to the House of Commons for first reading, Tom McMillan stated: "Like the Draft Bill, the revised Act sets out $\$ 1$ million-a-day fines against polluters, no maximum fines for certain offences - so-called crimes against the environment - and jail terms of up to five years... [and] corporate chief executive officers will be held legally accountable" (McMillan). It notes that during the preceding decade, there had not been a single federal government prosecution under the preceding legislation and that "the country's record in enforcing environmental law has been appalling" (McMillan). What the speech does not do is refer to the basic fact laid out in the 1974 document discussed above, that regulation and enforcement through prosecutions in the Canadian system is done by the provinces, with federal regulation being the exception. In the ten years from 1988 to 1998, the federal government prosecuted 232 infractions, while one province, Ontario, laid 13,229 charges (Mittelstaedt). It is true that CEPA provided for coercive enforcement, but the federal government has never really used the potential powers highlighted by the minister at the time.

A companion document by Environment Canada, undated but likely from 1987 since the title refers to the "proposed" Act, made as its major claim that CEPA would provide "the legislative framework for the better management of chemicals ... from research and development to introduction, through manufacture, transportation, distribution, use and, ultimately, to disposal." Although in more muted language, it too highlighted the million-dollars-per-day fines, and in addition federal "leadership" and "regulations ... applicable to federal lands." The primary claim for environmental legitimacy made in these two documents is the exaggerated statement that the federal government is tough on environmental crime. The others are the same as those made in 1985- moving forward in a way not done by previous governments and providing leadership.

\section{The 1990 Green Plan}

Following the 1988 election, which resulted in the re-election of the Mulroney government, Lucien Bouchard became the first Environment Canada Minister who clearly had the ear of the prime minister. Shortly afterward, he left the government to establish the Bloc Québécois and went on to fight the 1995 referendum. "A close friend of the prime minister ... [Bouchard] strode into the DOE [Department of Environment] knowing he had a prime-ministerial mandate to devise a Green Plan and he set about doing so" (Doern and Conway 49). The plan relied primarily upon the 
policy instrument of spending (three billion dollars over five years), rather than regulation. Most of that money was never spent, however. $\$ 1.2$ billion was cut by the Mulroney government in the 1991 and 1992 budgets (78) and the plan was then cancelled by the Liberals after they came to power in 1993. In retrospect, it is clear that the plan was far closer to a pure public relations exercise than were any of the previously discussed policy actions.

What follows is the identification of the claims for environmental legitimacy made in the "Statement by the Prime Minister" and "Statement by the Minister of the Environment," provided as prefaces to the Green Plan (Government of Canada, 1990). Four major claims were made: (1) the need to integrate economic and environmental decision making, associated with the emergence of the sustainable development paradigm (a new theme); (2) the need to co-operate with a new stress upon co-operation with individual Canadians; (3) the plan was a significant step forward; and, (4) the process by which the plan was developed was legitimate because it was transparent and consultative.

After referring to the historical importance of the Canadian environment and natural resources, the brief prime minister's message (about 200 words) stated: "The challenge we now face is to build upon our economic strengths in harmony with our environment..." (Government of Canada, 1990 1). The prime minister's statement ends with "The Green Plan will help Canada be a country which is both economically prosperous and environmentally healthy" (1). For the first time, we find federal government action presented in the context of sustainable development.

Sustainable development is described, in general, as activity in which the environment is fully incorporated into the economic decision-making process as a forethought, not an afterthought. ... We Canadians know from our own experience that economic growth is essential ... [there must be] a fundamental change in the way we use the environment in our pursuit of economic growth. (Government of Canada, 1990 4-5)

The second theme in the prime minister's statement is co-operation with individual citizens: "Every Canadian has a role to play in achieving this goal of sustainable development" (Government of Canada, 1990 1). The statement emphasizes the "Government's commitment to work with Canadians" (1). The minister's statement refers to co-operation with individual Canadians. Thirdly, the statement refers to the fact that the plan "was developed in consultation with Canadians from all walks of life"(1).

In the minister's statement, we find the familiar claim that it was a significant step forward, in fact the most significant to that date, the "most important environmental action plan ever produced in Canada" (2). The claim of process legitimacy resulting from consultation was made several times. The minister stated that he had spent the "past summer ... listening to 
Canadians" and pointed to the fact that " 400 of the 500 recommendations" made at the final consultation session had been included in the plan (2).

\section{The 1992 Canadian Environmental Assessment Act}

Environmental assessment is the process used to predict the environmental impacts of a project during its planning stages and then design the project in order to minimize those impacts. During the $1970 \mathrm{~s}$, most provinces enacted environmental assessment laws, while the federal government relied upon non-legislative policy for assessment of projects under federal jurisdiction. Only when forced by court actions, did the federal government enact a law (Boyd 151).

The speech by the Minister, Robert de Cotret, on the day he presented the draft Canadian Environmental Assessment Act to the House of Commons made four claims to environmental legitimacy: (1) the government was committed to act on the issue; (2) the bill was a significant step forward, more important than anything done in the area to date by his or previous governments; (3) the process for developing the CEAA was consultative, as would be the environmental assessment process itself under the Act; and, (4) the bill would place Canada in a position of world leadership. The first page of the speech advances the first two claims - "this Government is committed to action ... These initiatives are a major step forward ... [providing] an "improved ... process." Relative to the third claim, the bulk of the speech described the environmental assessment for projects under federal jurisdiction, emphasizing its accessibility and transparency. While the closing paragraphs refer to the "inputs from two years of extensive consultations" during the development of the act, the fourth claim is summarized in the following: "I want to point out that Canada is among the first nations in the world to implement environmental assessment of policy [as opposed to physical projects]." Boyd (151) refers to the minister's comments as "hyperbole."

\section{The 1992 Rio Conference}

Canada's participation in the 1992 United Nations Conference on Environment and Sustainable Development, unlike the other five policy initiatives examined here, is an instance of Canadian environmental foreign policy. This is significant because in foreign policy the federal government plays the dominant role, albeit with a need to consult the provinces, thus avoiding the basic problem of limited capacity for action found in domestic regulations. Two documents were used to obtain examples of the image presented by the Government of Canada at this particular moment on the world stage - the "National Statement" to the conference made by the Minister of Environment, Jean Charest, on June 11, 1992 and an address to the conference by Prime Minister Mulroney the next day. 
In those two documents, we find five claims to environmental legitimacy, all of them by now familiar: (1) the sustainable development argument that policy will benefit the economy as well as the environment; (2) leadership; (3) co-operation; (4) process legitimacy; and, (5) comparisons with other countries. The minister's national statement referred almost immediately to the work of the World Commission on the Environment and Development, chaired by Gro Brundtland, and pointed to the fact that "Canada was one of four countries" visited by the Commission during its research (Charest 2). The 1990 Green Plan was then presented as "an action plan for sustainable development" (2) The closing words of the statement were a call to "build a world of sustainable development" (7). The prime minister stated that "sustainable development is not a slogan; it is a prerequisite of our prosperity and a safeguard of our identity" and also that "[t]he reconciliation of economic development and environmental preservation is not only necessary, it is inescapable" (Mulroney 1).

Both statements repeatedly referred to leadership, by calling upon the nations represented at Rio to take leadership action and by proudly pointing to that already taken by the Government of Canada. The minister explicitly stated that the ability to lead flowed from the legitimacy associated with sustainable development. "Governments as trustees must lead. To lead effectively, they must have the moral authority to do so. The challenge to governments everywhere in this complex, interrelated and rapidly changing world is to take the decisions which put us on the path to sustainable development. ... In Canada we have acted" (Charest 3).

The minister made his co-operation claim by stating that his government had "reached out to all sectors of Canadian society" (2). In terms of the fourth claim, the minister said: "The foundation of Canada's Green Plan has been transparency, accountability and inclusion" (2). These three elements were repeated in the speech and then again in the conclusion, in which the minister said that peoples of the world will hold leaders accountable for the Rio decisions, will expect to be included in those decisions, and that the Rio process must be transparent (7). Finally, the fifth claim was made by the prime minister, when he referred to the recently concluded Canada-US Air Quality Agreement as "one of the most significant bilateral environmental agreements between any two countries in recent years" (Mulroney 1992).

\section{The 2002 Climate Change Plan}

For the ten years following the Rio conference, the federal and provincial governments worked together to develop national climate change policy. In the face of strong resistance by industry and oil-producing provinces such as Alberta, only the relatively toothless policy instrument of appeals for voluntary action was used (Simpson, et al.; Macdonald). Since those provinces were unwilling to participate in national policy making once the 
Chrétien government decided in 2002 to ratify the Kyoto Protocol, the federal government proceeded to develop its own policy. The 2002 plan announced in November (Government of Canada, 2002) relied primarily upon two instruments, spending and "covenants" with large greenhouse gas emitting firms, a type of contract, and thus closer to regulatory action than the previous voluntary program.

Speaking in the House of Commons to lead off the debate on ratification of the Kyoto Protocol, the minister of the day, David Anderson, made four claims. The first, stressed repeatedly in the speech, was the way in which the plan would engender co-operation amongst all relevant actors: "We have worked closely with other partners, both at home and abroad..." (Anderson 1)" He referred to "our determination to build a consensus" (2) and said that "[f]rom the beginning of this process, we have sought to develop a collaborative relationship with many Canadian partners ..." (4), referring to provinces and territories, industry, labour and municipalities. The claim of co-operation with the provinces is a clear case of exaggeration, given the fact that his government's decision to ratify had brought an end to the federal-provincial process. Secondly, the speech claimed process legitimacy from consultations to plan development. Thirdly, it pointed to leadership: "I want to discuss the leadership that Canada is showing at home and internationally ..." (1). This claim is very much an exaggeration, given the failure of Canadian policy to that date. Finally, although far from being the dominant theme, which was very much co-operation, reference is made to the sustainable development theme of a "robust economy and an environment that we could enjoy, too" (6). Despite the fact that his government was moving to regulate industry, the word did not appear in the speech. Instead, the minister said: "Industry will be asked for no more than $55 \mathrm{MT}$ in reductions" (6).

\section{The 2007 Climate Change Plan}

By the time the Liberal Martin government fell in late 2006, it had published regulatory requirements for industrial reductions in the Canada Gazette, under the authority of CEPA. In 2006, the Harper government extended the deadlines for industry compliance, but in the face of rising concerns over the issue registered in public opinion polls, it was forced to replace both its original plan and the minister (Macdonald, 2008). In the spring of 2007, the Harper government announced its second plan. That plan was essentially a continuation of previous Liberal policy (Macdonald, 2008). The accompanying news release, however, is in sharp contrast to Minister Anderson's 2002 speech. The first sentence contained two claims-being tough on environmental crime and taking more significant action than previous governments: "the federal government [will] for the first-time ever force industry to reduce greenhouse gases and air pollution" (Environment Canada, 2007 1). Given the regulatory action of the Martin government, the latter claim is at best an exaggeration and at worst not true. 
The third claim was that this plan exceeded that of other countries: "Canada now has one of the most aggressive plans to tackle greenhouse gases and air pollution in the world" (1). This too is an exaggeration, given the fact that Canada is the only signatory country to have explicitly abandoned the reduction target it accepted in the Kyoto Protocol. Finally, the sustainable development theme is referred to: "These tough industrial regulations ... will have many positive economic effects" (1). The dominant claim, however, like that in the 1988 CEPA speech, was tough on environmental crime.

\section{Conclusion}

The table below lists the claims identified above with respect to the seven policy actions examined.

\section{Table 1. Environmental legitimacy claims 1985-2007}

\begin{tabular}{|c|c|}
\hline Program & Claims \\
\hline 1985 acid rain & $\begin{array}{l}\text { concerned } \\
\text { - exceeds previous governments } \\
\text { leadership } \\
\text {. exceeds other countries }\end{array}$ \\
\hline 1988 CEPA & $\begin{array}{l}\text { tough on environmental crime } \\
\text { - exceeds previous governments } \\
\text { leadership }\end{array}$ \\
\hline 1990 Green Plan & $\begin{array}{l}\text { - sustainable development } \\
\text { - co-operation } \\
\text { - exceeds previous governments } \\
\text { - process }\end{array}$ \\
\hline $\begin{array}{l}1992 \text { Canadian Environmental } \\
\text { Assessment Act }\end{array}$ & $\begin{array}{l}\text { - concerned } \\
\text { - process (both to develop and EA itself) } \\
\text { - exceeds previous governments } \\
\text { - exceeds other countries }\end{array}$ \\
\hline 1992 Rio Conference & $\begin{array}{l}\text { sustainable development } \\
\text { - leadership } \\
\text { - co-operation } \\
\text { - process } \\
\text { - exceeds other countries }\end{array}$ \\
\hline 2002 climate change & $\begin{array}{l}\text { - co-operation } \\
\text { - leadership } \\
\text { - process } \\
\text {. sustainable development }\end{array}$ \\
\hline 2007 climate change & $\begin{array}{l}\text { tough on environmental crime } \\
\text { - exceeds previous governments } \\
\text { - exceeds other countries } \\
\text {. sustainable development }\end{array}$ \\
\hline
\end{tabular}


The frequency of these eight claims, from most to least, is as follows.

- exceeds previous governments

6

- exceeds other countries

4

- sustainable development

- process

- leadership

- co-operation

- concerned
4

4

3

3

2

The central question explored here-How has the federal government worked to project an image of environmental legitimacy?-concerns the second of the three means of obtaining legitimacy discussed above. Conclusions in answer to that question are provided here, followed by a brief discussion of the other two means, changing behaviour and attempting to change the relevant norms.

In the instances examined here, the federal government has used three major strategies to present itself, its policies and the relevant policy development process as being environmentally legitimate. The most common strategy was to draw a favourable comparison, either with other governments or with other countries. Particularly in terms of the former, this is an application of the normal methods of partisan politics in the new arena of environmental policy, and as such is hardly surprising. Secondly, we find that the federal government has compensated for its regulatory inactivity in two ways: it has downplayed the role of provincial regulations (for instance, with respect to the national acid rain program or the non-regulatory Green Plan); and it has exaggerated the importance of direct federal regulation when it did occur (for instance, motor vehicle standards for acid rain, CEPA, and the Harper government 2007 climate regulations). Thirdly, as noted, legitimacy claims were almost always based upon exaggeration and hyperbole. The misleading statement by the Harper government that it would "for the first-time ever force industry to reduce greenhouse gases" (Environment Canada, 2007 1) is an extreme version, but the same tendency to shade the truth was found throughout. Again not too surprisingly, the federal government has engaged in greenwashing as part of its search for environmental legitimacy.

What are the implications of these methods of image projection? It seems likely that they have contributed to the environmental policy failures referred to at the outset. We lack empirical data on the success of this claims-making activity-the extent to which the voting public since 1985 has believed that its federal government was in fact a legitimate actor, putting in place effective policy. To the extent that they did, however, pressure on the federal government to take effective action was dulled. 
What about the times the federal government has also used the first of the three strategies and changed its own behaviour? It seems clear that such things as the Mulroney government activism of the late 1980s (Harrison) and the Harper redirection of climate change policy back to more stringent regulation (Macdonald, 2008) were prompted by rising levels of public concern. This behaviour change, however, largely provided ammunition for the second strategy of image projection. The Mulroney government's Green Plan certainly contributed to that government's environmental legitimacy image, but accomplished little. Similarly, the Harper government solved its environmental legitimacy deficit, but at the end of the day, the policy itself was only a return to that of its predecessor. Because they were able to obtain the needed environmental legitimacy as much by image as by action, we find that even when the first strategy was used, policy effectiveness was dulled.

Finally, we must say a word about the third strategy. It is very clear that after the early 1990 s, the federal government eagerly contributed to the construction of the new environmental norm of environmental protection coupled with economic growth, purely for anthropocentric reasons. Here, perhaps, is the true importance of environmental legitimacy as a factor in environmental politics. By joining business and environmentalists at the new centre of mainstream environmental politics, the federal government helped to preclude fundamental change in the arc of capitalist development. The search for environmental legitimacy is an important component of societal attitudes which influence environmental politics.

\section{Note}

* This paper was originally titled "Giving the Appearance of Action: Government Rhetoric Respecting its Environmental Regulation, 1970-2007" delivered at the conference Canada Exposed/Le Canada à découvert, International Conference on Canadian Studies, May 28, 2008.

\section{Works Cited}

Anderson, David (Dec: 9, 2009). "Notes for an address by The Honourable David Anderson, P.C., M.P. Minister of the Environment to open the Parliamentary debate on ratification of the Kyoto Protocol."

Barker, Rodney (1990). Political Legitimacy and the State. Oxford: Clarendon Press.

Baumgartner, Frank R. and Beth L. Leech (1998). Basic Interests: The Importance of Groups in Politics and in Political Science Princeton: Princeton University Press.

Beetham, David (1991). The Legitimation of Power. London: Macmillan.

Blais-Grenier, Suzanne Minister of the Environment (March 6, 1985). Notes for an address.

Boyd, David (2003). Unnatural Law: Rethinking Canadian Environmental Law and Policy. Vancouver: UBC Press

Carter, Neil (2001). The Politics of Environment: Ideas, Activism, Policy. Cambridge: Cambridge University Press.

Charest, Jean (June 11, 1992). "National Statement of Canada to the United Nations Conference on Environment and Development.", 
Connolly, William (1984). "Introduction: Legitimacy and Modernity." In William Connolly, ed. Legitimacy and the State. Oxford: Basil Blackwell.

Cotton, Roger and Kelley M. McKinnon (1993). "An Overview of Environmental Law in Canada," in Geoffrey Thompson, Moira L. McConnell and Lynne B. Heustis, eds. Environmental Law and Business in Canada. Aurora, Ont.: Canada Law Book.

de Cotret, Robert, Minister of the Environment (June 18, 1990). Statement Introducing the Canadian Environmental Assessment Act.

Doern, G. Bruce (2002). "Environment Canada as a Networked Institution.” In Debora VanNijnatten and Robert Boardman, eds. Canadian Environmental Policy: Context and Cases Second Edition. Toronto: Oxford University Press.

Doern, G. Bruce and Thomas Conway (1994). The Greening of Canada: Federal Institutions and Decisions. Toronto. University of Toronto Press.

Dryzek, John S. (1997). The Politics of the Earth: Environmental Discourses. Oxford: Oxford University Press.

Environment Canada (1974). Environment Canada: Its role, goals and organization. Ottawa: Information Canada.

Environment Canada (March 6, 1985). News Release: Federal acid rain control program unveiled - landmark decision in environmental protection.

Environment Canada (1995-96). Environment Canada Action Plan 1995/96-1997-98.

Environment Canada (undated - presumably 1987). The Right to a Healthy Environment: Highlights of the Proposed Environmental Protection Act.

Environment Canada (2003). Environmental Signals: Canada's National Environmental Indicator Series 2003.

Environment Canada (April 26, 2007). News release: “Canada's New Government Announces Mandatory Industrial Targets to Tackle Climate Change and Reduce Air Pollution."

Franck Thomas M. (1990). The Power of Legitimacy Among Nations. New York: Oxford University Press.

Galloway, Gloria (May 29, 2009). "Emissions rules delayed to match U.S. timetable." The Globe and Mail, A12.

Government of Canada (1990). Canada's Green Plan for a healthy environment. Ottawa: Minister of Supply and Services.

Government of Canada (2002.) Climate Change Plan for Canada: Achieving our Commitments Together.

Government of Canada (2005). Moving Forward on Climate Change: A Plan for Honouring our Kyoto Commitment.

Greenpeace (May, 1992). The Greenpeace Book of Greenwash. Vancouver: Greenpeace.

Hajer, Maarten A. (1995). The Politics of Environmental Discourse: Ecological Modernization and the Policy Process. Oxford: Clarendon Press.

Harrison, Kathryn (1996). Passing the Buck: Federalism and Canadian Environmental Policy. Vancouver: UBC Press.

Howlett, Michael and Rebecca Raglon (1992). "Constructing the Environmental Spectacle: Green Advertisements and the Greening of the Corporate Image, 1910-1990."

Environmental History Review, winter, 1992, 52-68.

Lafferty, William M. (2000). Implementing Sustainable Development: Strategies and Initiatives in High Consumption Societies. New York: Oxford University Press.

Macdonald, Doug (1991). The Politics of Pollution: Why Canadians Are Failing Their Environment. Toronto: McClelland and Stewart

- - (1997). Policy Communities and Allocation of Internalized Cost: Negotiation of the Ontario Acid Rain Program, 1982-1985. PhD dissertation, Faculty of Environmental Studies, York University. (2007). Business and Environmental Politics in Canada. Peterborough: Broadview Press.

. "Climate-change policy making by the Stephen Harper government: a case study of the relationship between public opinion and environmental policy"; paper 
delivered at the annual meeting of the Canadian Political Science Association, UBC, June 6, 2008.

- (2009). "Explaining the Failure of Canadian Climate Change Policy." In Hugh Compston and lan Bailey, eds. Turning Down the Heat: The Politics of Climate Policy in Affluent Countries. Palgrave Macmillan.

Macdonald, Douglas, Andrew Bjorn and Debora L. VanNijnatten (2004). "Implementing Kyoto: When Spending is Not Enough." G. Bruce Doern, ed., How Ottawa Spends: 2004-05. Montreal and Kingston: McGill-Queen's University Press.

McMillan, Tom Minister of the Environment (June 26, 1987). Statement on the first reading in Parliament of the Canadian Environmental Protection Act.

Mitchell, Neil J. (1997). The Conspicuous Corporation: Business, Public Policy, and Representative Democracy. Ann Arbor: The University of Michigan Press.

- (1989). The Generous Corporation: A Political Analysis of Economic Power. New Haven: Yale University Press.

Mittelstaedt, Martin (March 23, 1999) "Criminal polluters finding Canada the promised land." The Toronto Globe and Mail.

Mulroney, Brian Prime Minister (June 12, 1992). Notes for an address: Earth Summit, Rio de Janeiro, Brazil.

Nash, Roderick (1989). The Rights of Nature: A History of Environmental Ethics. Madison: University of Wisconsin Press.

Outhwaite, William "legitimacy" (1993). In William Outhwaite and Tom Bottomore eds., The Blackwell Dictionary of Twentieth-Century Social Thought. Oxford: Blackwell.

Scharpf, Fritz (1999). Governing in Europe: Effective and Democratic? Oxford: Oxford University Press.

Shabecoff, Philip ( ${ }^{\text {nd }}$ edition 2003). A Fierce Green Fire: The American Environmental Movement. Washington, D.C.: Island Press.

Simpson, Jeffrey, Mark Jaccard and Nic Rivers (2007). Hot Air: Meeting Canada's Climate Change Challenge. Toronto: McClelland and Stewart.

Skogstad, Grace (2003). "Who Governs? Who Should Govern?: Political Authority and Legitimacy in Canada in the Twenty-First Century." Canadian Journal of Political Science, 36:5, 955-973.

Source Watch Enclyclopedia http://www.sourcewatch.org/index.php?title=Greenwash, June 2, 2009.

Suchman, Mark C. (1995). "Managing legitimacy: Strategic and institutional approaches," The Academy of Management Review. vol. 20, no. 3, pp. 571-602.

Winfield, Mark (1994). "The Ultimate Horizontal Issue: The Environmental Policy Experiences of Alberta and Ontario, 1971-1993." Canadian Journal of Political Science, XXVII, 1, pp. 129-152.

Winfield, Mark and Douglas Macdonald (2008). "The Harmonization Accord and Climate Change Policy: Two Case Studies in Federal-Provincial Environmental Policy." In Herman Bakvis and Grace Skogstad, eds., Canadian Federalism: Performance, Effectiveness and Legitimacy, Don Mills: Oxford University Press. 